\title{
The Evaluation of Catheter Infections in Kidney Disease Patients
}

\section{Böbrek Hastalığı Olan Hastalarda Kateter Enfeksiyonlarının Değerlendirilmesi}

\author{
Pervin Ozkan Kurtgoz', Ibrahim Guney', @Suleyman Karakose', @Mustafa Topal', \\ Dedip Erkus', DArzu Tarakci²
}

University of Health Sciences, Konya Training and Research Hospital, Department of Nephrology, Konya, Turkey 2University of Health Sciences, Konya Training and Research Hospital, Department of Clinical Microbiology and Infectious Diseases, Konya, Turkey

\begin{abstract}
Aim: In our study, we aimed to review the factors retrospectively that may be related to catheter infection $(\mathrm{Cl})$ in patients who received hemodialysis (HD) treatment in our clinic and followed up due to $\mathrm{Cl}$.

Material and Method: The files of 105 patients who were hospitalized in the Nephrology clinic or Intensive Care Unit (ICU) and who were diagnosed as $\mathrm{Cl}$ while on $\mathrm{HD}$ treatment were analyzed retrospectively.

Results: Forty-seven (44.8\%) of the patients were male, 58 (55.2\%) were female and the mean age was $62.3 \pm 17.6$ (19-90). The average length of hospital stay of the patients was 16 (2-60) days and the infection was mortal in $16(15.2 \%)$ patients. In the cultures taken from the catheters, in 51 (48.6\%) patients $\mathrm{Gr}(+)$ bacteria, in 24 (22.9\%) patients $\mathrm{Gr}(-)$ bacteria and in $2(1.9 \%)$ patients fungi were detected. There was no reproduction in 26 (24.8\%) catheter cultures. The methicillin resistance (MR) was $87.6 \%$ and the highest resistance was detected in Coagulase Negative Staphylococcus (CNS) and S. aureus culture samples. $43(41.0 \%)$ of the patients didn't respond to antibiotics during treatment and catheter exchange was required in these patients. Catheter replacement requirement was significantly higher in the $\mathrm{Gr}(-)$ bacterial group (14 patients, 58.3\%) $(p=0.050)$.

Conclusion: To prevent $\mathrm{Cl}$, it is important to reveal the factors related to infection. Microbiological agent distribution and resistance rate of each clinic and HD unit are different. Antibiotherapy should be planned according to this agent distribution to decrease antibiotic resistance.
\end{abstract}

Keywords: Kidney disease, catheter infections, gram negative bacteria, hemodialysis

\section{Öz}

Amaç: Çalışmamızda kliniğimizde hemodiyaliz (HD) tedavisi gören ve kateter enfeksiyonu nedeniyle takip edilen hastalarda, kateter enfeksiyonu ile ilişkili olabilecek faktörleri gözden geçirmeyi amaçladık.

Gereç ve Yöntem: Nefroloji kliniğinde veya Yoğun Bakım Ünitesinde (YBÜ) yatan ve HD tedavisi sırasında kateter enfeksiyonu tanısı alan 105 hastanın dosyası retrospektif olarak incelendi.

Bulgular: Hastaların 48'i $(\% 44,8)$ erkek, 58'i $(\% 55,2)$ kadın ve ortalama yaş 62,3 $\pm 17,6$ (19-90) idi. Hastaların ortalama hastanede kalış süresi 16 $(2-60)$ gün ve $16(\% 15,2)$ hastada enfeksiyon mortaldi. Kateterlerden alınan kültürlerde $51(\% 48,6)$ hastada Gr $(+)$ bakteri, $24(\% 22,9)$ hastada Gr $(-)$ bakteri ve $2(\% 1,9)$ hastada mantar tespit edildi. $26(\% 24,8)$ kateter kültüründe üreme olmadı. Metisilin direnci (MR) \%87,6 idi ve en yüksek direnç, Koagülaz Negatif Stafilokok (KNS) ve S. aureus kültür örneklerinde saptandı. Hastaların 43'ü $(\% 41,0)$ tedavi sırasında antibiyotiklere yanıt vermedi ve bu hastalarda kateter değişimi gerekti. Kateter replasman gereksinimi Gr (-) bakteri grubunda anlamlı olarak daha yüksekti (14 hasta, \%58,3) ( $p=0,050)$.

Sonuç: Kateter enfeksiyonunu önlemek için enfeksiyonla ilişkili faktörleri ortaya koymak önemlidir. Her bir klinik ve HD ünitesinin mikrobiyolojik ajan dağılımı ve direnç oranı farklıdır. Antibiyotik direncini azaltmak için antibiyoterapi bu ajan dağılımına göre planlanmalıdır.

Anahtar Kelimeler: Böbrek hastalığı, kateter enfeksiyonları, gram negatif bakteri, hemodiyaliz

Corresponding (illetişim): Pervin Özkan Kurtgöz, University of Health Sciences, Konya Training and Research Hospital, Department of Nephrology, Konya, Turkey

E-mail (E-posta): dr.pervinozkan@gmail.com

Received (Geliş Tarihi): 09.05.2020 Accepted (Kabul Tarihi): 25.11.2020 


\section{INTRODUCTION}

The best vascular access pathway in HD is arteriovenous fistula (AVF). Other options are arteriovenous graft (AVG) and catheters. Generally for the first HD a catheter is using because of unmaturated AVF. Today, tunnelled catheters with double lumen and a cuff are used to reduce the risk of infection in medium and long term. ${ }^{1}$ The most common complications in HD patients are cardiovascular events and infections, these are the most important causes of hospitalizations. Infections related to vascular access routes constitute approximately $28 \%$ of infection related hospitalizations in chronic kidney disease (CKD). ${ }^{2}$ Infection risk in tunneled catheters is 10 times higher than AVF and AVG. ${ }^{3}$ Compared to patients with AVF, catheterized patients had $53 \%$ increase in all-cause mortality risk, 2-3 fold increase in risk of fatal and non-fatal infection, and $68 \%$ increase in hospitalization risk, respectively. ${ }^{4}$

Frequent occurrence of $\mathrm{Cl}$ brings with it other problems. Patients whose hospitalizations are frequent and prolonged have additional problems and the rate of resistance to antibiotics increases due to frequent using of antibiotics. Therefore, newer and more expensive treatments are used. ${ }^{2}$ For these reasons, more studies are needed to explain the causes of $\mathrm{Cl}$, related factors and methods of protection from infections. In this study, we reviewed the factors retrospectively that may be related to $\mathrm{Cl}$ in patients who received $\mathrm{HD}$ treatment in our clinic and followed up due to $\mathrm{Cl}$.

\section{MATERIAL AND METHOD}

\section{Patient Characteristics and Exclusion Criterias}

In this study, the culture results of the blood samples taken from the HD catheter, peripheral vein and catheter tip of 450 patients with kidney disease who were hospitalized in the Nephrology clinic or ICU between July 2016 and February 2020 were analyzed, retrospectively. Ethical approval for the study was obtained. $\mathrm{Cl}$ was defined as the infection in a patient with concomitant clinical signs of infection and no other source of infection other than catheter and also concomitant growth of the same microorganism from the peripheral vein, catheter or catheter tip culture. ${ }^{3}$

According to culture results, $\mathrm{Cl}$ were determined in 105 of 450 patients and these patients were included in the study. The remaining 345 patients were excluded from the study for reasons such as infection focus other than catheter, not being able to make a clear diagnosis of $\mathrm{Cl}$ and the presence of ongoing infection before catheter insertion. Patients' age, gender, cause of CKD, additional diseases, location where the catheter was inserted, temporary or permanent catheter type, application complaint, dialysis duration, catheter culture result, methicillin sensitivity, hospital stay, ICU hospitalization, mortality rates and laboratory data were recorded.

\section{Catheter Insertion}

HD catheters were inserted in a sterilized environment by interventional radiology or cardiovascular surgeons. The insertion area of the catheter was sterilized with a mixture of $2 \%$ glutaraldehyde and $70 \%$ ethyl alcohol. Internal jugular vein, femoral vein and subclavian vein were preferred for catheter insertion. The catheters were closed by dressing with chlorhexidine after each dialysis session.

\section{Obtaining of Cultures}

The sowing of the catheter samples was carried out in accordance with the semi-quantitative culture and quantitative culture techniques. The culture plates were evaluated after 48 hours incubation at $37^{\circ} \mathrm{C}$ and $>15 \mathrm{CFU}$ in the semantictative culture. In quantitative culture $>1000 \mathrm{CFU} / \mathrm{ml}$ growth was considered as significant. Blood cultures from peripheral venous blood and from the catheter were evaluated in the BACTEC FX 9120 (Becton Dickinson, USA) automated blood culture device. Identification of isolated bacteria was carried out using conventional methods and where necessary, fully automated identification systems (VITEC 2 Compact, Biomerieux, France). Antibiotic susceptibility tests were performed using a fully automated system according to the criteria of "European Committee on Antimicrobial Susceptibility Testing (EUCAST)".

\section{Statistical Analysis}

SPSS 22.0 version was used for statistical analysis. Results were shown as \pm standard deviations and frequencies. Variables were evaluated using the Kolmogorov-Smirnov test for normality of distribution. In comparison of categorical variables, Fisher's exact test and Chi-square test were used according to their suitability. In the comparison of the two groups, those with normal distribution were performed with the T-test and those without normal distribution were performed with the Mann Whitney $\mathrm{U}$ test. If the $\mathrm{p}$ value was less than 0.05 , the statistically was considered as significant.

\section{RESULTS}

Forty seven (44.8\%) of the patients were male, $58(55.2 \%)$ were female, and the mean age was $62.3 \pm 17.6$ (age range 19-90). The mean dialysis time was $3.14 \pm 3.5$ (3-19) years and $9(8.6 \%)$ patients due to acute kidney disease (AKD), 96 (91.4\%) patients due to CKD were on dialysis treatment. Diabetes mellitus (DM) (35 patients, 33.3\%) and hypertension (HT) (23 patients, $21.9 \%$ ) were the most common etiologies of CKD patients. The most common complaint of patients was chills-tremor (58.1\%). Seventy-three (69.5\%) patients were hospitalized from nephrology polyclinic, 32 (30.5\%) patients developed $\mathrm{Cl}$ during their hospitalization. The mean hospitalization time of the patients was 16 (2-90) days and the infection was mortal in $16(15.2 \%)$ patients. In 15 (14.3\%) patients, there was a history of ICU hospitalization and in 14 of these patients the infection was mortal. Cl recurred in 29 (27.6\%) of patients after treatment and they hospitalizated again. The demographic data of the patients are given in Table 1. 


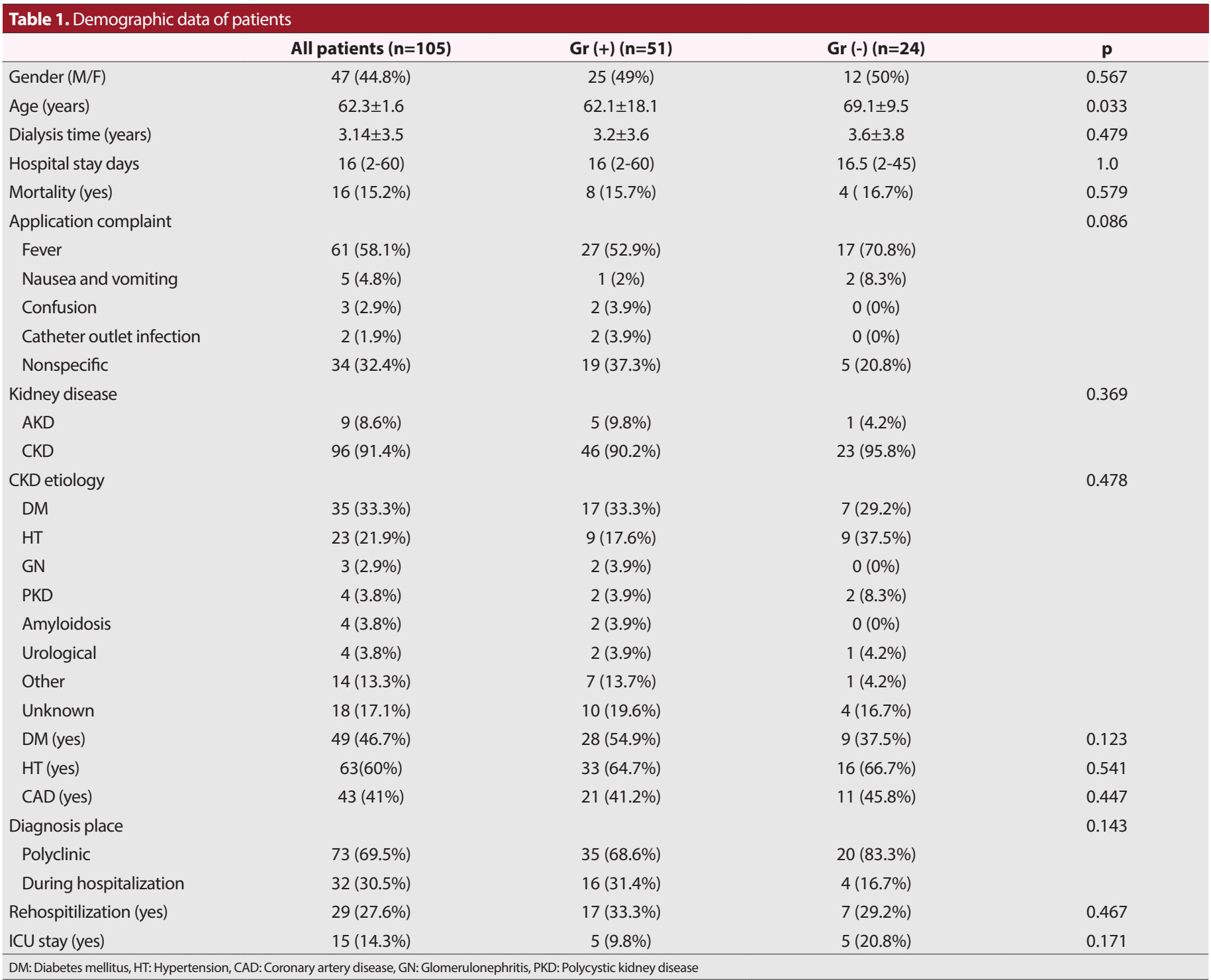

The patients were grouped as Gr (+) and Gr (-) bacteria group according to catheter culture results. In the cultures taken from the catheter, in 51 (48.6\%) patients Gr (+) bacteria, in 24 (22.9\%) patients $\mathrm{Gr}(-)$ bacteria and in $2(1.9 \%)$ patients fungi were growth. The status of patients related to $\mathrm{Cl}$ is indicated in Table 2. When the demographic data of the patients are compared between the two groups, the average age was higher in the $\operatorname{Gr}(-)$ bacterial group $(p=0.033)$ but in other datas there was no statistically significant differences (Table 1).

Gr (+) bacterias $(51,48.6 \%)$ were the most frequently detected microorganisms according to culture results and among 35 (33.3\%) of them were CNS, 11 (10.5\%) were S. aureus. In Gr (-) bacteria group (24, 22.9\%) Enterobacter species (9, 8.9\% ) was the most common agent. The other encountered $\mathrm{Gr}$ (-) bacterias were as follows; Pseudomonas (1, 1\%), E. coli $\operatorname{ESBL}(+)(3,2.9 \%)$, E. coli $\mathrm{ESBL}(-)(3,2.9 \%)$, Klebsiella ESBL (+) $(3,2.9 \%)$, Klebsiella ESBL (-) (1, 1\%), Acinetobacter (3, 2.9\%), Stenotrophomonas maltophilia (1, 1\%). Candida was detected in $2(1.9 \%)$ patients. The rate of MR was $87.6 \%$, and the highest resistance was detected in CNS and $S$. aureus species. There was no growth of bacteria in the catheter cultures of remaining $26(24.8 \%)$ patients.

In $43(41.0 \%)$ patients needed catheter replacement during their treatment. When all Gr (-) bacteria group were examined, more than half $(14,58.3 \%)$ required catheter replacement during treatment and this rate was significantly higher compared to $\mathrm{Gr}(+)$ bacteria group $(p=0.05)$. Catheter exchange was required in all patients with Pseudomonas, Stenotrophomonas maltophilia, ESBL (+) E. coli and Klebsiella (Table 3).

The Gr (-) bacteria group had lower CRP $(p=0.046)$ and sedimentation $(p=0.022)$ values and higher calcium levels $(p=0.044)$ when compared to the $\mathrm{Gr}(+)$ bacteria group. There were no statistically significant difference between the other laboratory values of the two groups (Table 4). 


\begin{tabular}{|c|c|c|c|}
\hline All patients $(n=105)$ & $\operatorname{Gr}(+)(n=51)$ & $\operatorname{Gr}(-)(n=24)$ & $\mathbf{p}$ \\
\hline $82(78.1 \%)$ & $41(80.4 \%)$ & 19 (79.2\%) & \\
\hline $10(9.5 \%)$ & $4(7.8 \%)$ & $1(4.2 \%)$ & \\
\hline $1(1 \%)$ & $0(0 \%)$ & $0(0 \%)$ & \\
\hline & & & 0.236 \\
\hline \multicolumn{4}{|c|}{ Catheter culture result } \\
\hline $26(24.8 \%)$ & & & \\
\hline $2(1.9 \%)$ & & & \\
\hline $51(48.6 \%)$ & & & \\
\hline $24(22.9 \%)$ & & & \\
\hline $0(0 \%)$ & $0(0 \%)$ & $0(0 \%)$ & \\
\hline $2(1.9 \%)$ & $1(2 \%)$ & $0(0 \%)$ & \\
\hline $0(0 \%)$ & $0(0 \%)$ & $0(0 \%)$ & \\
\hline $103(98.1 \%)$ & $50(98 \%)$ & $24(100 \%)$ & \\
\hline
\end{tabular}

\begin{tabular}{|c|c|c|c|c|}
\hline & All patients $(n=105)$ & Methicillin resistant & Methicillin sensitive & Catheter replacement (yes) \\
\hline No reproduction & $26(24.8 \%)$ & & & $9(20.9 \%)$ \\
\hline Contaminated & $2(1.9 \%)$ & & & $1(2.3 \%)$ \\
\hline CNS & 35 (33.3\%) & $34(66.6 \%)$ & $1(1.9 \%)$ & 15 (34.9\%) \\
\hline Enterococcus & $5(4.7 \%)$ & $0(0.0 \%)$ & $5(9.6 \%)$ & $1(2.3 \%)$ \\
\hline Enterobacter & $9(8.9 \%)$ & & & $4(9.3 \%)$ \\
\hline E. coli ESBL (+) & $3(2.9 \%)$ & & & $3(7.0 \%)$ \\
\hline E. coli ESBL (-) & $3(2.9 \%)$ & & & $0(0.0 \%)$ \\
\hline Klebsiella ESBL (+) & $3(2.9 \%)$ & & & $3(7.0 \%)$ \\
\hline Klebsiella ESBL (-) & $1(1 \%)$ & & & $0(0.0 \%)$ \\
\hline Acinetobacter & $3(2.9 \%)$ & & & $1(2.3 \%)$ \\
\hline
\end{tabular}

\begin{tabular}{|c|c|c|c|c|}
\hline & All patients $(n=105)$ & $\operatorname{Gr}(+)(n=51)$ & $\operatorname{Gr}(-)(n=24)$ & $\mathbf{p}$ \\
\hline $\mathrm{Hb}$ & $10.0 \pm 1.8$ & $10.2 \pm 1.9$ & $10.5 \pm 1.4$ & 0.547 \\
\hline WBC & $10.5 \pm 5.4$ & $10.7 \pm 6.6$ & $10.4 \pm 3.0$ & 0.856 \\
\hline CRP & $87.28 \pm 69.33$ & $95.7 \pm 61.9$ & $78.5 \pm 84.5$ & 0.046 \\
\hline Procalcitonin & $15.31 \pm 25.33$ & $16.2 \pm 27.3$ & $21.7 \pm 29.9$ & 0.078 \\
\hline Sedimantation & $54.3 \pm 28.1$ & $56.3 \pm 28.0$ & $42.2 \pm 20.0$ & 0.022 \\
\hline $\mathrm{Na}$ & $136.0 \pm 4.2$ & $135.4 \pm 4.6$ & $136.4 \pm 3.3$ & 0.312 \\
\hline K & $4.7 \pm 0.9$ & $4.7 \pm 0.9$ & $5.0 \pm 1.0$ & 0.161 \\
\hline $\mathrm{Ca}$ & $8.9 \pm 0.8$ & $8.7 \pm 0.8$ & $9.0 \pm 0.5$ & 0.044 \\
\hline$P$ & $3.9 \pm 2.2$ & $3.9 \pm 2.2$ & $3.8 \pm 2.2$ & 0.532 \\
\hline Albumin & $3.1 \pm 0.5$ & $3.1 \pm 0.4$ & $3.1 \pm 0.6$ & 0.914 \\
\hline Üric acid & $4.8 \pm 2.1$ & $4.9 \pm 2.2$ & $4.5 \pm 2.0$ & 0.443 \\
\hline
\end{tabular}




\section{DISCUSSION}

Vascular access infections are common in HD patients and often require hospitalization. $\mathrm{Cl}$ rates are a reportable parameter and also are a benchmark and performance indicator for both hospital and dialysis facilities. ${ }^{5} \mathrm{Cl}$ are an important problem for HD patients worldwide, so we evaluated the factors related to $\mathrm{Cl}$ with this study. In our study, 105 patients who were followed with $\mathrm{Cl}$ were admitted with the most common chills-tremors complaint and mostly hospitalized from polyclinic. In one third of the patients, $\mathrm{Cl}$ developed during hospitalization. The development of such a high rate of $\mathrm{Cl}$ during hospitalization may be due to factors such as frequent hospitalization of patients, prolonged hospitalization, presence of multiple drug resistant (MDR) bacteria in our clinic and ICU hospitalization for a different reason.

DM and HT were the most common etiologies of CKD in our study. Raji et al. ${ }^{5}$ found that catheter-related complications were higher in CKD patients due to DM. There was some of our patients whose blood glucose levels could not be regulated. Hyperglycemia in uncontrolled DM increases the risk of infection, thrombosis and catheter failure due to bacterial growth, immunosuppression and increased vascular insufficiency. ${ }^{6,7}$ There are studies reporting that infection rate is high especially in patients with multisystemic disease in CKD etiology. ${ }^{8}$ Other risk factors related to $\mathrm{Cl}$ are aging, long-term hospitalization, frequent use of antibiotics, duration of catheter, malnutrition, hypoalbuminemia. ${ }^{9}$ The average age of our patients was $62.3 \pm 17.6$ and the mean age was higher in the group with $\mathrm{Cl}$ due to $\mathrm{Gr}$ (-) bacterias. Our study was retrospective, no clear information about catheter duration, frequency of antibiotic use and nutritional status could be obtained.

In $\mathrm{HD}$ patients, $\mathrm{Gr}(+)$ bacteria are predominant in $\mathrm{Cl}$ and the most common bacteria is $S$. aureus. In the HD population, $S$. aureus infection is 100 times more common than the general population. ${ }^{10}$ Vascular access infections with $S$. aureus are one of the worst clinical scenarios in HD patients. It is potentially not only mortal but can also cause loss of vascular access despite the timely removal of infected grafts and catheters. ${ }^{11}$ At the same time, S. aureus infections can cause metastatic infections such as endocarditis, osteomyelitis. In our study, the most common bacteria was CNS, second frequent agent was $S$. aureus and in only one patient osteomyelitis was detected. In our study, MR was $87.6 \%$ and this rate was higher compared to other studies. Nyugen et al. ${ }^{12}$ Alhazmi et al. ${ }^{11}$ reported the resistance of S. aureus methicillin as 40\% and 50\%, respectively. Fram et al. ${ }^{13}$ reported that the use of previous antimicrobial drugs caused more and higher resistant infections. Reason of higher MR in our study might be the that our clinic serves as the third step facility so that there might be the presence of MDR microorganisms, frequent and broad spectrum antibiotic use and frequent hospitalization of patients. In a quarter of our patients had no reproduction in their cultures. This can be seen when there is a recent history of antibiotic use, presence of bacteria that can't be produced, and the difficulties associated with delivering the culture to the laboratory.
Although $\mathrm{Gr}(+)$ bacteria are predominant in $\mathrm{Cl}$, the frequency and dominance of Gr (-) bacteria have increased recently. In a recent study on the relationship between $\mathrm{Gr}$ (-) bacteria and $\mathrm{Cl}$, Murray et al. ${ }^{14}$ reported 95 cases of $\mathrm{Gr}(-)$ bacteremia in 84 patients from 1242 HD patients (0.175 / 1000 HD days). Interestingly, the source of $\mathrm{Gr}(-)$ bacteria was found to be associated with vascular access in only $29.5 \%$ of patients ( $16.8 \%$ catheter related). While urinary, biliary, intraabdominal and infected foot ulcers were identified as the source in $53.7 \%$ of the remaining patients, no source could be found in $16.8 \%$. The most frequent isolated $\mathrm{Gr}(-)$ agents were as follows E. coli (47.5\%), Enterobacter (13.1\%) and Klebsiella (11.1\%) respectively. While the first 3-month mortality was $28.6 \%$, the mortality in 3 years was $46.4 \% .^{14}$ In other studies related to $\mathrm{Gr}$ (-) bacteria in ICU patients, mortality was found to be $48 \%$ in the first 30 days and $60 \%$ in the study duration (0.178 / 1000 ICU day1.13 / 1000 ICU day). ${ }^{15,16}$ In our study, Gr (-) bacteria was grown in $22.9 \%$ of the patients and Enterobacter was most common and $E$. coli was the second common agents. In studies, the dominance of Enterobacter was frequently associated with hospitalization or ICU hospitalization. ${ }^{14}$ Some studies have associated frequent hospitalization with the risk of $P$. aeruginosa. ${ }^{17}$ Our mortality rate due to $\mathrm{Gr}(-)$ bacteria was $16.7 \%$. Murray et al. ${ }^{14}$ linked the cause of high mortality due to $\mathrm{Gr}(-)$ to the late removal of catheters because of vascular access restriction. The early removal of catheters in patients whom with positive control culture results might be the cause of low mortality in our study.

Gr (-) infections have become important with increasing antibiotic resistance in recent years. ${ }^{18}$ In most countries, the rate of MRSA decreases while the rate of MDR Gr (-) bacteria increases. ${ }^{21}$ MDR Gr (-) bacteria ratio is high in HD patients. ${ }^{22}$ The non-fermented Gr (-) bacterias such as Acinetobacter, Pseudomonas aeruginosa and Stenotrophomonas maltophilia are highly resistant to antibiotics and catheter replacement may be required, as in our study. Pop-vicas et al. ${ }^{21}$ reported Gr (-) bacterial colonization in HD patients. Colonization risk factors are common use of antibiotics and frequent hospitalizations. The way to prevent $\mathrm{Gr}(-)$ bacteremia is to start with antibiotics which include both $\mathrm{Gr}(+)$ and $\mathrm{Gr}(-)$ bacteria and rearrange the antibiotic treatment after a definitive microbiological diagnosis. ${ }^{18}$ Candida was observed in 2 patients' catheter culture hospitalized in ICU. ICU hospitalization, colonization of the mucous membranes and insertion of permanent intravascular catheters are the main predisposing factors for Candida infections. ${ }^{22,23}$

Laboratory parameters are also important for the identification of $\mathrm{Cl}$. Acute phase reactants increase in infectious situations but are insufficient to determine the type of bacteria. CRP concentrations increase in the presence of bacterial infections and are higher in $\mathrm{Gr}(+)$ bacteremia than in $\mathrm{Gr}(-)$ bacteremia. In the case of Gr (-) bacteremia, procalcitonin levels increase. It was reported in the literatüre that procalcitonin levels and baseline CRP values were unrelated to local infection, systemic infection and mortality but affect the length of hospital stay. ${ }^{24}$ CRP, sedimentation and procalcitonin values were above normal in our patients. Sedimentation $(p=0.022)$ and CRP $(p=0.046)$ were higher in $\mathrm{Cl}$ due to $\mathrm{Gr}(+)$ bacterias. 
Although the average calcium levels of our patients were normal but calcium levels were lower in the $\mathrm{Gr}(+)$ bacterial group ( $p=0.044$ ). Although our data was different, Zaloga et al. reported that that all patients had normal calcium levels before sepsis, but during $\mathrm{Gr}(-)$ bacterial septic attack hypocalcaemia had developed and during $\mathrm{Gr}(+)$ bacterial sepsis it had remained in normal ranges. Hypocalcemia might develop as a result of disruption in calcitriol synthesis due to the renal failure that developed during sepsis. In addition, it was determined that hypotensive patients had more severe hypocalcemia and that hypocalcemia was associated with high mortality during sepsis. ${ }^{25}$

\section{CONCLUSIONS}

As a result; $\mathrm{Cl}$ are common in patients on dialysis and are associated with serious mortality and morbidity. To prevent $\mathrm{Cl}$, it is important to reveal infection related factors. Microbiological agent distribution and resistance rate of each clinic and HD unit are different. Antibiotherapy should be planned according to this factor distribution to reduce antibiotic resistance. The frequency of $\operatorname{Gr}(-)$ infections with high mortality increased nowadays therefore when starting empirical treatment antibiotherapy must be regulated according to this knowledge.

\section{ETHICAL DECLARATIONS}

Ethics Committee Approval: The study was carried out with the permission of Sağlık Bilimleri University Konya Training and Research Hospital Medical Specialty Education Board (Permission granted: 06.02.2020, Decision no: 35-35).

Informed Consent: Because the study was designed retrospectively, no written informed consent form was obtained from patients.

Referee Evaluation Process: Externally peer-reviewed.

Conflict of Interest Statement: The authors have no conflicts of interest to declare.

Financial Disclosure: The authors declared that this study has received no financial support.

Author Contributions: All of the authors declare that they have all participated in the design, execution, and analysis of the paper, and that they have approved the final version.

\section{REFERENCES}

1. Hemodialysis Adequacy 2006 Work Group. Clinical practice guidelines for hemodialysis adequacy, update 2006. Am J Kidney Dis 2006;48(1):1-10.

2. Camins BC. Prevention and treatment of hemodialysis related bloodstream infections. Semin Dial 2013;26(4):476-81.

3. Böhlke M, Uliano G, Barcellos F. Hemodialysis catheter-related infection: prophylaxis, diagnosis and treatment. The J of Vasc Access 2015;16(5):34755.

4. Ravani P, Palmer SC, Oliver MJ et al. Associations between hemodialysis access type and clinical outcomes: a systematic review. J Am Soc Nephrol 2013;24(3):465-73.

5. Raji YR, Ajayi SO, Aminu O et al. Outcomes of tunneled internal jugular venous catheters for chronic haemodialysis at the University College Hospital, Ibadan, Nigeria. Pan Afr Med J 2018;31:218.
6. Vats HS. Complications of catheters: tunneled and non-tunneled. Adv Chronic Kidney Dis 2012;19(3):188-94.

7. Fry AC, Stratton J, Farrington K et al. Factors affecting long-term survival of tunneled haemodialysis catheters: a prospective audit of 812 tunneled catheters. Nephrol Dial Transplant 2008;23(1):275- 81.

8. Centers for Disease Control and Prevention (CDC). Reducing bloodstream infections in an outpatient hemodialysis center New Jersey, 2008-2011. MMWR Morb Mortal Wkly Rep 2012;61(10):169-73.

9. Alhazmi SM, Noor SO, Alshamrani MM et al. Bloodstream infection at hemodialysis facilities in Jeddah: a medical record review. Ann Saudı Med 2019;9(4):258-64.

10. Centers for Disease Control and Prevention (CDC). Invasive methicillin resistant Staphylococcus aureus infections among dialysis patients United States, 2005. MMWR Morb Mortal Wkly Rep 2007;56(9):197-9.

11. Chu C, Wong MY, Tseng YHet al.Vascular access infection by Staphylococcus aureus from removed dialysis accesses. Microbiology Open 2019;8:1-10.

12. Nguyen DB, Lessa FC, Belflower $\mathrm{R}$ et al. Invasive methicillin resistant Staphylococcus aureus infections among patients on chronic dialysis in the United States, 2005-2011. Clin Infect Dis 2013;57(10):1393-400.

13. Fram D, Okuno MF, Taminato M et al. Risk factors for bloodstream infection in patients at a Brazilian hemodialysis center: a case-control study. BMC Infectious Dis 2015;15:158-65.

14. Murray EC, Marek A. Thomson PC et al. Gram-negative bacteraemia in haemodialysis. Nephrol Dial Transplant 2015;30:1208-17.

15. Mermel LA, Allon M, Bouza E et al. Clinical practice guidelines for the diagnosis and management of intravascular catheter-related infection 2009 Update by the Infectious Diseases Society of America. Clin Infect Dis 2009;49:1-45.

16. Ashby DR, Power A, Singh S et al. Bacteremia associated with tunneled hemodialysis catheters: outcome after attempted salvage. Clin J Am Soc Nephrol 2009;4:1601-5.

17. Al-Hasan MN, Eckel-Passow JE, Baddour LM. Impact of healthcare associated acquisition on community onset Gram-negative bloodstream infection: A population-based study. Eur J Clin Microbiol Infect Dis 2012;31:1163-71.

18. Girndt M. Bacteraemia in haemodialysis patients-not always Staphylococcus aureus. Nephrol Dial Transplant 2015;30:1055-7.

19. European Centre for Disease Prevention and Control. Antimicrobial resistance interactive database (EARS-Net) antimicrobial resistance. April 2015

20. Calfee DP. Multidrug-resistant organisms in dialysis patients. Semin Dial 2013;26:447-56.

21. Pop-Vicas A, Strom J, Stanley K et al. Multidrug-resistant gram-negative bacteria among patients who require chronic hemodialysis. Clin J Am Soc Nephrol 2008;3:752-8

22. Dimopoulos G, Karabinis A, Samonis G et al. Candidemia in immunocompromised and immunocompetent critically ill patients: A prospective comparative study. Eur J Clin Microbiol Infect Dis 2007;26(6):377-84.

23. Blumberg HM, Jarvis WR, Soucie JM et al. Risk factors for candidal bloodstream infections in surgical intensive care unit patients: The NEMIS prospective multicenter study. The National Epidemiology of Mycosis Survey. Clin Infect Dis 2001;33(2):177-86.

24. Kargaltseva NM, Kotcherovets $\mathrm{VI}$, Mironov AY et al. Inflammation markers and bloodstream infection (review of literature). Clin Lab Diagn 2019;64(7):435-42.

25. Zaloga GP, Chernow B. The multifactorial basis for hypocalcemia during sepsis studies of the parathyroid hormone-vitamin D axis. Ann Intern Med 1987;107:36-41. 